\title{
Comparison of transpiration between different aged black locust (Robinia pseudoacacia) trees on the semi-arid Loess Plateau, China
}

\author{
JIAO Lei ${ }^{1,2}$, LU Nan $^{1,2^{*}}$, FU Bojie ${ }^{1,2}$, GAO Guangyao ${ }^{1,2}$, WANG Shuai ${ }^{1,2}$, JIN Tiantian $^{3}$, \\ ZHANG Liwei ${ }^{4}$, LIU Jianbo ${ }^{1,2}$, ZHANG $\mathrm{Di}^{5}$ \\ ${ }^{1}$ State Key Laboratory of Urban and Regional Ecology, Research Center for Eco-Environmental Sciences, Chinese Academy of \\ Sciences, Beijing 100085, China; \\ ${ }^{2}$ Joint Center for Global Change Studies, Beijing 100875, China; \\ ${ }^{3}$ China Institute of Water Resources and Hydropower Research, Beijing 100038, China; \\ ${ }^{4}$ College of Tourism and Environment, Shaanxi Normal University, Xi'an 710119, China; \\ ${ }^{5}$ College of Earth and Environmental Science, Lanzhou University, Lanzhou 730000, China
}

Abstract: Black locust (Robinia pseudoacacia) is widely planted throughout the semi-arid Loess Plateau of China. The spatial distribution of this species at different ages is highly heterogeneous due to restoration and management practices. In this study, we aimed to compare the transpiration levels between different aged black locusts at the tree and stand scales, clarifying the physiological status of this species with different ages. Black locust trees with two representative age classes (12 and 28 years) were selected in the Yangjuangou catchment on the semi-arid Loess Plateau. Sap flux density $\left(F_{d}\right)$ and environmental variables (solar radiation, air temperature, relative humidity and soil water content) were simultaneously monitored throughout the growing season of 2014. Tree transpiration $\left(E_{t}\right)$ was the product of $F_{d}$ and sapwood area $\left(A_{s}\right)$, and stand transpiration $\left(E_{c}\right)$ was calculated basing on the stand sap flux density $\left(J_{s}\right)$ and stand total sapwood area $\left(A_{S T}\right)$. Stomatal conductance $\left(g_{s}\right)$ was measured in a controlled environment and hydraulic conductance was estimated using the relationship between transpiration rate and vapor pressure deficit (VPD). Our results showed that $E_{t}$ and $E_{c}$ were higher in the 28-year-old stand than in the 12-year-old stand. The $g_{s}$ and hydraulic conductance of 28-year-old trees were also higher than those of 12-year-old trees, and the two parameters were thus the causes of variations in transpiration between different age classes. After rainfall, mean $F_{d}$ increased by $9 \%$ in 28-year-old trees and by $5 \%$ in 12-year-old trees. This study thus suggests that stand age should be considered for estimating transpiration at the catchment and region scales in this area. These results provide ecophysiological evidences that the older black locust trees had more active physiological status than the younger ones in this area. These findings also provide basic information for the management of water resources and forests on the semi-arid Loess Plateau.

Keywords: sapflow; transpiration; stand age; afforestation; restoration; Loess Plateau

Citation: JIAO Lei, LU Nan, FU Bojie, GAO Guangyao, WANG Shuai, JIN Tiantian, ZHANG Liwei, LIU Jianbo, ZHANG Di. 2016. Comparison of transpiration between different aged black locust (Robinia pseudoacacia) trees on the semi-arid Loess Plateau, China. Journal of Arid Land, 8(4): 604-617. doi: 10.1007/s40333-016-0047-2

Forests are potential water consumers which can influence the water balance of ecosystems (Vertessy et al., 2001). Previous studies have shown that stand age is a crucial factor influencing

*Corresponding author: LU Nan (E-mail: nanlv@rcees.ac.cn)
Received 2015-12-10; revised 2016-02-29; accepted 2016-03-15
C Xinjiang Institute of Ecology and Geography, Chinese Academy of Sciences, Science Press and Springer-Verlag Berlin Heidelberg 2016 
the consumption capacity of forests (Alsheimer et al., 1998; Zimmermann et al., 2000; Cornish and Vertessy, 2001; Köstner et al., 2002; Forrester et al., 2010; Röll et al., 2015). In cases of afforestation after a fire or harvest, annual water yield in watershed initially decreases and then increases to the pre-afforestation level with increasing age of trees over a long-term period. This phenomenon is generally thought to be the result of variations in transpiration along an age series of trees (Roberts et al., 2001; Scott and Prinsloo, 2008). For a watershed with high spatial heterogeneity (due to management practices) in forest classes, investigating variations in transpiration of forests at different ages is thus crucial for assessing water balance (Delzon and Loustau, 2005).

Age-related change in physiological characteristics of trees is a major contributing factor to the variations in transpiration both at the tree and stand scales (Irvine et al., 2004; Delzon and Loustau, 2005; Ewers et al., 2005). Previous studies have shown that both the tree hydraulic redistribution and hydraulic conductance vary as the changes of tree size and height with ages, and the factors that control stomatal conductance $\left(g_{s}\right)$ to maintain an appropriate water potential gradient from soil-to-leaf and so as to avoid hydraulic failure (Ryan and Yoder, 1997; Ryan et al., 2000). Reduction in $g_{s}$ induced by hydraulic limitations subsequently constrains both transpiration water loss and photosynthesis (Schulze et al., 1994; McDowell et al., 2002; Magnani et al., 2008). Examining hydraulic conductance and $g_{s}$, therefore, can provide physiological evidence to interpret transpiration variation among trees with different ages (Ewers et al., 2005). In addition, roots system is another factor that impacts the transpiration of trees and stands (David et al., 2007; David et al., 2013; Thomsen et al., 2013). The effect of drought on younger and smaller trees with shallower roots was higher than that on older and larger trees with deeper roots (Kume et al., 2007). The differences in the roots systems of different aged trees determine the impact degree of soil drought on transpiration of trees (Delzon and Loustau, 2005).

Loess Plateau in China is characterized by severe soil erosion and degraded ecosystems. To control soil erosion and restore ecosystem function, government implemented afforestation projects beginning in the 1950s (Wang et al., 2004; Jin et al., 2011; Chen and Tang, 2016) and carried out afforestation campaign in the later 1980s (Wang et al., 2004). At the end of the 1990s, the "Grain for Green" project was established to protect the environments (Fu et al., 2000; Wang et al., 2011; Liu and Shao, 2016). Black locust (Robinia pseudoacacia), an exotic species, was selected as a dominant plant species for afforestation in this area due to its fast growth and drought tolerance (Jin et al., 2011; Li et al., 2014). However, the age of the black locust trees across the Loess Plateau is not uniform, because afforestation is implemented over several decades.

Water shortage is also a serious problem in this region, wherein reduction in water yield after afforestation has become a large concern in recent years (Sun et al., 2006; Feng et al., 2012). Transpiration levels in black locust plantations thus become a central focus due to their potential impact on water resources at the watershed and regional scales (Du et al., 2011; Chen et al., 2014; Jiao et al., 2015). Previous studies mainly focused on the stand transpiration $\left(E_{c}\right)$ within black locust stands at a single age (Wang et al., 2010; Jian et al., 2015; Zhang et al., 2015), and there were few studies on the levels of transpiration variation in trees and stands with different ages. Wang et al. (2010) and Zhang et al. (2015) quantified the $E_{c}$ of an approximately 30-year-old black locust stand on the Loess Plateau, with the value of $0.32-0.49 \mathrm{~mm} / \mathrm{d}$ during the growing seasons (accounting for $10 \%-12 \%$ of the potential evapotranspiration $\left(\mathrm{ET}_{0}\right)$ )), which was rather lower than that of the deciduous forests in the other regions (Bréda et al., 1995; Santiago et al., 2000). Based on field surveys, some researchers believed that the possible reason for lower $E_{c}$ is the degradation of black locust within approximately 30-year-old trees (Wang et al., 2001; Wang et al., 2004; Wang et al., 2010). Moreover, studies on $E_{c}$ and ecophysiological characteristics related to water movement among different aged black locust trees are absent. However, such studies would provide useful information for investigating the water requirements of different aged black locust trees and clarify the possible reasons.

This study analyzed the transpiration of black locust stands at two representative age classes (12 and 28 years) on semi-arid area of the Loess Plateau, China. The aim was to investigate the potential differences in transpiration at the tree and stand scales between two different aged black 
locust stands as well as analyze their ecophysiological mechanisms. Specifically, this study aimed to: (1) compare transpiration of black locust at the tree and stand scales between 12-year-old and 28-year-old stands; (2) determine the causes of transpiration difference between the two representative ages; and (3) clarify the physiological status of trees between the two ages by comparing transpiration, $g_{s}$, hydraulic conductance and response of transpiration to rainfall.

\section{Materials and methods}

\subsection{Study area}

This study was conducted in the Yangjuangou catchment $\left(36^{\circ} 42^{\prime} \mathrm{N}, 109^{\circ} 31^{\prime} \mathrm{E}\right.$; Fig. 1) within the central Loess Plateau, a typically loess hilly and gully region in China. The catchment comprises an area of $2.02 \mathrm{~km}^{2}$ with altitude ranging from 1,050 to $1,295 \mathrm{~m}$ (Liu et al., 2012). The annual mean air temperature is $9.8^{\circ} \mathrm{C}$. The mean annual precipitation from 1952 to 2012 was $531.0 \mathrm{~mm}$. The growing season is from May to September for most deciduous species, during which the mean air temperature is $20.0^{\circ} \mathrm{C}$ with the mean precipitation of $421.7 \mathrm{~mm}$ (1952-2012).

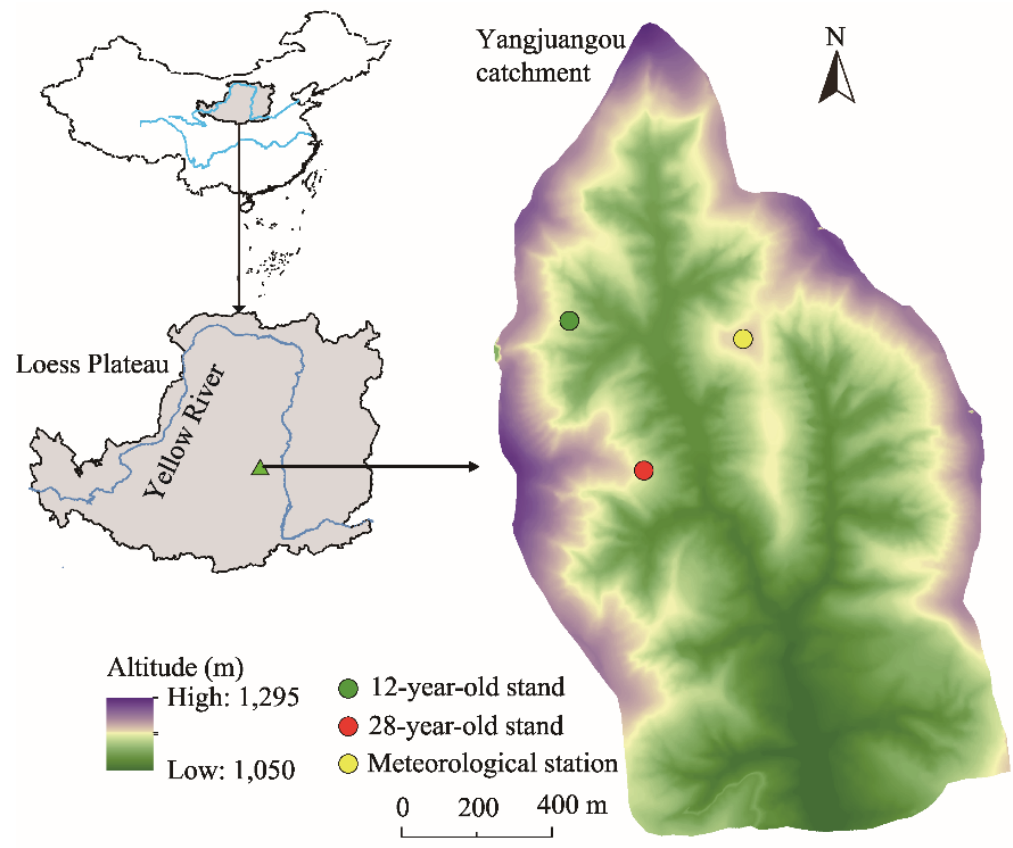

Fig. 1 Geographical locations of the studied black locust stands with different ages and the meteorological station in the Yangjuangou catchment, Loess Plateau of China

\subsection{Experimental stands, age determination and sapwood analysis}

The study area is the main region for the aforementioned afforestation campaigns, in which black locust was planted in the later 1980 s and early 2000 s to restore the abandoned hillslope farmlands. Currently, the black locust trees in this area are thus either $<15$ years or approximately 30 years. The density for afforestation in this catchment is nearly 2,500 trees $/ \mathrm{hm}^{2}$. No management practices were performed on these trees after planting. In this study, a younger stand and an older stand with similar topographical condition, slope aspect (east), slope degree (approximately $23^{\circ}$ ), slope position (lower) and altitude (approximately 1,170 m) were selected for the experiment. The area of each stand is $10 \mathrm{~m} \times 10 \mathrm{~m}$. Field survey was conducted for each stand at the beginning of the growing season of 2014 (Table 1).

To determine stand age and calculate sapwood area $\left(A_{s} ; \mathrm{cm}^{2}\right)$, we selected 26 sample trees beside the younger stand and 28 sample trees beside the older stand. An increment core was taken at breast height (1.3 $\mathrm{m}$ aboveground) in each sample tree for determining the age of each tree via 
tree-ring analysis. The tree-ring was analyzed in the laboratory after the core was dried, glued and sanded. Then, we determined that the younger stand was 12 years and the older stand was 28 years in 2014.

Table 1 Parameters of the black locust with different ages at the stand and tree scales in the Yangjuangou catchment $($ mean \pm SD)

\begin{tabular}{|c|c|c|c|}
\hline & Parameter & 12-year-old stand & 28-year-old stand \\
\hline \multirow[t]{17}{*}{ Stand } & Direction & East & East \\
\hline & Slope degree $\left({ }^{\circ}\right)$ & 24 & 26 \\
\hline & Elevation $(\mathrm{m})$ & 1,169 & 1,172 \\
\hline & Age (a) & 12 & 28 \\
\hline & Mean height (m) & $6.94 \pm 1.80$ & $8.93 \pm 1.63$ \\
\hline & Mean $D B H(\mathrm{~cm})$ & $5.59 \pm 1.66$ & $11.76 \pm 4.38$ \\
\hline & Density (trees $/ \mathrm{hm}^{2}$ ) & 2,500 & 1,200 \\
\hline & $\operatorname{LAI}\left(\mathrm{m}^{2} / \mathrm{m}^{2}\right)$ & $2.77 \pm 0.41$ & $2.38 \pm 0.42$ \\
\hline & $A_{S T}\left(\mathrm{~cm}^{2}\right)$ & 373.43 & 314.75 \\
\hline & Mean $A_{s}\left(\mathrm{~cm}^{2}\right)$ & $14.94 \pm 9.62$ & $22.21 \pm 13.53$ \\
\hline & Mean $T_{s}(\mathrm{~cm})$ & $0.89 \pm 0.56$ & $0.77 \pm 0.10$ \\
\hline & Mean $T_{b}(\mathrm{~cm})$ & $0.51 \pm 0.22$ & $0.92 \pm 0.22$ \\
\hline & Mean $T_{h}(\mathrm{~cm})$ & $2.29 \pm 1.48$ & $4.20 \pm 1.87$ \\
\hline & Soil BD at the depth of $0-40 \mathrm{~cm}\left(\mathrm{~g} / \mathrm{cm}^{2}\right)$ & 1.23 & 1.21 \\
\hline & \multirow{3}{*}{$\begin{array}{l}\text { Soil particle composition at the depth } \\
\text { of } 0-100 \mathrm{~cm}(\%)\end{array}$} & 3.52 (Clay) & 3.42 (Clay) \\
\hline & & 66.51 (Silt) & 60.67 (Silt) \\
\hline & & 29.97 (Sand) & 35.91 (Sand) \\
\hline \multirow[t]{7}{*}{ Sample trees } & Sample number & 8 & 6 \\
\hline & Mean height (m) & $8.13 \pm 1.18$ & $9.50 \pm 1.70$ \\
\hline & Mean $D B H(\mathrm{~cm})$ & $6.95 \pm 1.25$ & $14.86 \pm 1.99$ \\
\hline & Mean $A_{\mathrm{s}}\left(\mathrm{cm}^{2}\right)$ & $22.58 \pm 8.55$ & $52.46 \pm 23.29$ \\
\hline & Mean $T_{s}(\mathrm{~cm})$ & $1.54 \pm 0.42$ & $0.84 \pm 0.04$ \\
\hline & Mean $T_{b}(\mathrm{~cm})$ & $0.47 \pm 0.10$ & $1.07 \pm 0.10$ \\
\hline & Mean $T_{h}(\mathrm{~cm})$ & $1.99 \pm 0.68$ & $5.52 \pm 0.85$ \\
\hline
\end{tabular}

Note: $D B H$, diameter at breast height; LAI, leaf area index; $A_{S T}$, total sapwood area of stand; $A_{s}$, sapwood area; $T_{\mathrm{s}}$, sapwood depth; $T_{b}$, bulk thickness; $T_{h}$, heartwood thickness; BD, bulk density. LAI was derived from the average monthly values from May through September during the growing season of 2014. $A_{S T}$, mean $A_{s}$ and mean $T_{s}$ were measured at breast height of the stem (1.3 $\mathrm{m}$ aboveground).

Bulk thickness $\left(T_{b} ; \mathrm{cm}\right)$, sapwood depth $\left(T_{s} ; \mathrm{cm}\right)$ and heartwood thicknesses $\left(T_{h} ; \mathrm{cm}\right)$ were easily distinguished due to different core colors. For trees with a small diameter at breast height $(D B H ; \mathrm{cm})$ aside from the 12-year-old stand, we conducted a harvest to determine the $T_{b}, T_{s}$ and $T_{h}$. We used a power regression to establish the relationship of $D B H$ and $A_{s}$ (Vertessy et al., 1995). The regressions of $A_{s}$ and $D B H$ for 12-year-old and 28-year-old stands were expressed as Eqs. 1 and 2 , respectively.

$$
\begin{aligned}
& A_{s}=0.28 \times D B H^{2.25}\left(R^{2}=0.99, n=26, P<0.001\right), \\
& A_{s}=0.25 \times D B H^{1.81}\left(R^{2}=0.95, n=28, P<0.001\right) .
\end{aligned}
$$

\subsection{Climate factors and soil water condition}

An automatic meteorological station (Dynamet, Dynamax Inc., Houston, TX, USA), which is located in an open space in the catchment, monitored the climate conditions at a distance of nearly $400 \mathrm{~m}$ from the studied stands (Fig. 1). Solar radiation $\left(R_{s} ; \mathrm{W} / \mathrm{m}^{2}\right)$ was measured by means of a pyranometer (LI-200, Campbell Scientific, Inc., Logan, UT, USA). Air temperature $\left(T_{a} ;{ }^{\circ} \mathrm{C}\right)$ and relative humidity $(R H ; \%)$ were measured using a shielded thermistor probe (HMP45, Campbell Scientific Inc., Logan, UT, USA) installed at $2 \mathrm{~m}$ aboveground. Precipitation (mm) was measured using a tipping-bucket rain gauge (TE525, Campbell Scientific Inc., Logan, UT, USA). The climate data were collected via a data logger (CR1000, Campbell Scientific Inc., Logan, UT, USA). Volumetric soil water content $\left(S W C ; \mathrm{m}^{3} / \mathrm{m}^{3}\right)$ was measured at depths of $10,20,40,60,80,100,150$ and $180 \mathrm{~cm}$ in both studied stands using soil moisture sensors (EC-5, Decagon Devices, Pullman, 
WA, USA), and recorded by a data logger (HOBO-H21, Onset Computers, Bounce, MA, USA). All data were measured at interval of $60 \mathrm{~s}$ and recorded every $30 \mathrm{~min}$. Vapor deficit pressure (VPD; $\mathrm{kPa})$ was calculated with $T_{a}$ and $R H$ according to the study of Campbell and Norman (1998).

\subsection{Sap flux measurement and calibration}

The individual tree sap flux density $\left(F_{d} ; \mathrm{kg} /\left(\mathrm{m}^{2} \cdot \mathrm{d}\right)\right)$ was measured using the thermal dissipation probes (TDP) from 15 May to 30 September, 2014. Eight trees were selected in the 12-year-old stand and 6 trees were selected in the 28-year-old stand (Table 1). Each sensor consisted of one upper probe and one lower probe, with $10 \mathrm{~mm}$ in length and $1.2 \mathrm{~mm}$ in diameter. The upper probe contained a heater supplied with $0.15 \mathrm{~W}$ of constant power, with the lower probe serving as the reference. The probe contained a copper-constantan thermocouple junction, and the temperature difference between the upper heater probe and the lower reference probe was measured. The probes were inserted in the sapwood at $1.3 \mathrm{~m}$ aboveground at the north aspect after first removing the bark. Aluminum-faced foams cover shielded the measuring point in the stem to avoid $R_{S}$. The data were measured at intervals of $60 \mathrm{~s}$ and recorded at intervals of $30 \mathrm{~min}$ in a data logger (CR1000, Campbell Scientific Inc., Logan, UT, USA) for each stand. We calculated $F_{d}$ according to the study of Granier (1987):

$$
F_{d}=86.4 \times 119 \times\left(\frac{\Delta T_{m}-\Delta T}{\Delta T}\right)^{1.231} .
$$

Where, $\Delta T\left({ }^{\circ} \mathrm{C}\right)$ is the temperature difference between the upper probe and the lower reference probe; $\Delta T_{m}\left({ }^{\circ} \mathrm{C}\right)$ is the maximum value of $\Delta T$ when $F_{d}$ is zero at night.

If the probe length is longer than $T_{s}$, calibration is necessary to avoid underestimating $F_{d}$. Calibration was conducted according to the following method (Clearwater et al., 1999):

$$
\Delta T_{s w}=\Delta T-\frac{\mathrm{b} \Delta T_{m}}{\mathrm{a}} .
$$

Where, $\Delta T_{S w}\left({ }^{\circ} \mathrm{C}\right)$ is the temperature difference in the sapwood; a is the proportion of probe in the sapwood; and b is the proportion of probe in the inactive xylem $(\mathrm{b}=1-\mathrm{a})$. The $\Delta T$ in Eq. 3 was replaced with $\Delta T_{s w}$.

To compare the probe length $(10 \mathrm{~mm})$ with the $T_{s}$ of sample trees, we established the relationship of $T_{s}$ with $D B H, T_{b}$ and $A_{s}$ according to the study of Zhang et al. (2015).

$$
T_{s}=\left(\frac{D B H}{2}-T_{b}\right) \pm \sqrt{\left(\frac{D B H}{2}-T_{b}\right)^{2}-\frac{A_{s}}{\pi}} .
$$

To calculate the $T_{b}$ of sample trees in each stand, we established the linear regressions of $T_{b}$ (reading from tree cores) and $\mathrm{DBH}$ for 12-year-old and 28-year-old stands (Eqs. 6 and 7, respectively).

$$
\begin{aligned}
& T_{b}=0.054 D B H+0.107\left(R^{2}=0.755, n=26, P<0.001\right), \\
& T_{b}=0.05 D B H+0.329\left(R^{2}=0.734, n=28, P<0.001\right) .
\end{aligned}
$$

\subsection{Calculations of tree and stand transpiration}

Tree transpiration $\left(E_{t} ; \mathrm{kg} / \mathrm{d}\right)$ was calculated using $F_{d}$ and $A_{s}\left(\mathrm{~m}^{2}\right)$ measured at breast height of the stem (Eq. 8).

$$
E_{t}=F_{d} \times A_{s} .
$$

Stand transpiration $\left(E_{c} ; \mathrm{mm} / \mathrm{d}\right)$ was estimated as Eq. 9 (Kumagai et al., 2008):

$$
E_{c}=J_{S} \times\left(A_{S T} / A_{G}\right) .
$$

Where, $A_{S T}\left(\mathrm{~m}^{2}\right)$ refers to the stand total sapwood area; $A_{G}\left(\mathrm{~m}^{2}\right)$ is the ground area; and $J_{S}$ $\left(\mathrm{kg} /\left(\mathrm{m}^{2} \cdot \mathrm{d}\right)\right)$ indicates the mean stand sap flux density, which can be calculated using Eq. 10 .

$$
J_{s}=\frac{\sum_{i=1}^{n} F_{d i} A_{s i}}{A_{S T}} .
$$

Where, $F_{d i}\left(\mathrm{~kg} /\left(\mathrm{m}^{2} \cdot \mathrm{d}\right)\right)$ is the mean $F_{d}$ of the $i^{\text {th }} D B H$ class and $A_{s i}\left(\mathrm{~m}^{2}\right)$ is the total $A_{s}$ of $i^{\text {th }} D B H$ class; $n$ is the number of $D B H$ classes. $D B H$ classes was determined at a 2 -cm interval according 
the frequency distribution of tree $D B H$ in each stand (Kumagai et al., 2008).

\section{$1.6 g_{s}$ measurement}

Stands with different structures (e.g. density, tree space and canopy gaps) can modify leaf stomatal conductance $\left(g_{s}\right)$ due to different solar radiations obtained by the trees (Teklehaimanot et al., 1991; Kupper et al., 2006; Sun et al., 2014). To compare the $g_{s}$ of trees in each stand under similar light conditions, we controlled light intensity in the experiment and measured $g_{s}$ using a portable infrared gas analyzer (Li-6400, Li-Cor, Lincoln, NE, USA). The light intensity within the leaf chamber was controlled according to the average photosynthetic active radiation (PAR; 1,475 $\mu \mathrm{mol} /\left(\mathrm{m}^{2} \cdot \mathrm{s}\right)$ for this study) from $10: 00$ to $11: 30$ on sunny days. In addition, the experiments were conducted from 10:00-11:30 on 21 July for the 28-year-old stand and on 24 July for the 12-year-old stand. On the experimental days, the mean $S W C$ was $0.117 \mathrm{~m}^{3} / \mathrm{m}^{3}$ in the 28 -year-old stand and $0.115 \mathrm{~m}^{3} / \mathrm{m}^{3}$ in the 12-year-old stand. Five trees with different $D B H$ s were selected in each stand, wherein five well-expanded leaves were measured from each tree, replicating three measurements for each leaf.

\section{7 $\quad F_{d^{-}}-V P D$ relationship and response of $F_{d}$ to rainfall}

To analyze the relationship between mean $F_{d}$ and $V P D$, we used an exponential saturation model (Ewers et al., 2002, 2007):

$$
F_{d}=\mathrm{x} \times\left(1-\mathrm{e}^{-\mathrm{y} \times V P D}\right) .
$$

Where, $\mathrm{x}$ and $\mathrm{y}$ are fitting parameters. To examine the responses of $F_{d}$ in each stand to water recharge from rainfall, we defined an increase in $F_{d}$ as follows (Kume et al., 2007):

$$
\text { Increase in } F_{d}=\left(\frac{f_{\text {after }(V P D)}}{f_{\text {before }(V P D)}}-1\right) \times 100 \% \text {. }
$$

Where, $f_{\text {after(VPD) }}$ is the fitting curve of the mean daily $F_{d}$ of sample trees versus daily VPD after rainfall using an exponential saturation model (Eq. 10); and $f_{\text {before }(V P D)}$ describes the curve of the mean daily $F_{d}$ of sample trees versus daily VPD before rainfall. Rainfalls lower than $3 \mathrm{~mm}$ which fell at intervals of $<5 \mathrm{~d}$ were excluded (Zhao and Liu, 2010). Twelve rainfall events were selected during the study period, and the data of the 2 days before and after rainfall were used for analysis.

\subsection{Statistical analysis}

A paired $t$-test was used to compare the differences in daily $E_{t}$ and $E_{c}$ between the two stands. All statistical analyses were performed with SPSS 16.0 software (SPSS Inc., Chicago, IL, USA).

\section{Results}

\subsection{Climate and soil water conditions}

Climate variables and soil water conditions in the study area are shown in Fig. 2. Average daily $R_{S}$ amounted to $209.9 \pm 91.9 \mathrm{~W} / \mathrm{m}^{2}$, ranging from 20.5 to $352.6 \mathrm{~W} / \mathrm{m}^{2}$ (Fig. 2a), and average daily $V P D$ was $0.97 \pm 0.55 \mathrm{kPa}$, ranging from 0.55 to $2.35 \mathrm{kPa}$ (Fig. 2b). During the study period, the stands received a total of $416 \mathrm{~mm}$ precipitation, with $87 \%$ of which occurring in July, August and September. Rainfall events significantly influenced the variation in daily $S W C$ (Fig. 2e). The mean SWC in the soil depth of 0-180 cm was significantly higher in the 28 -year-old stand than in the 12-year-old stand in May, August and September (paired $t$-test, $P<0.01$ ). The mean $S W C$ in the entire growing season was $0.115 \mathrm{~m}^{3} / \mathrm{m}^{3}$ in the 12 -year-old stand and $0.120 \mathrm{~m}^{3} / \mathrm{m}^{3}$ in the 28-year-old stand.

\subsection{Tree and stand characteristics}

The 12-year-old stand has a higher density than the 28-year-old stand, with 2,500 and 1,200 trees $/ \mathrm{hm}^{2}$, respectively (Table 1), possibly resulting from self-thinning during the succession process. The mean height of trees was $6.94 \mathrm{~m}$ for the 12-year-old stand and $8.93 \mathrm{~m}$ for the 28 -year-old stand. The mean $A_{s}$ was higher in the 28 -year-old stand $\left(26.2 \mathrm{~cm}^{2}\right)$ than in the 12-year-old stand $\left(15.8 \mathrm{~cm}^{2}\right)$, and higher $A_{s}$ was usually related to larger $D B H$. The mean $T_{s}$ of 

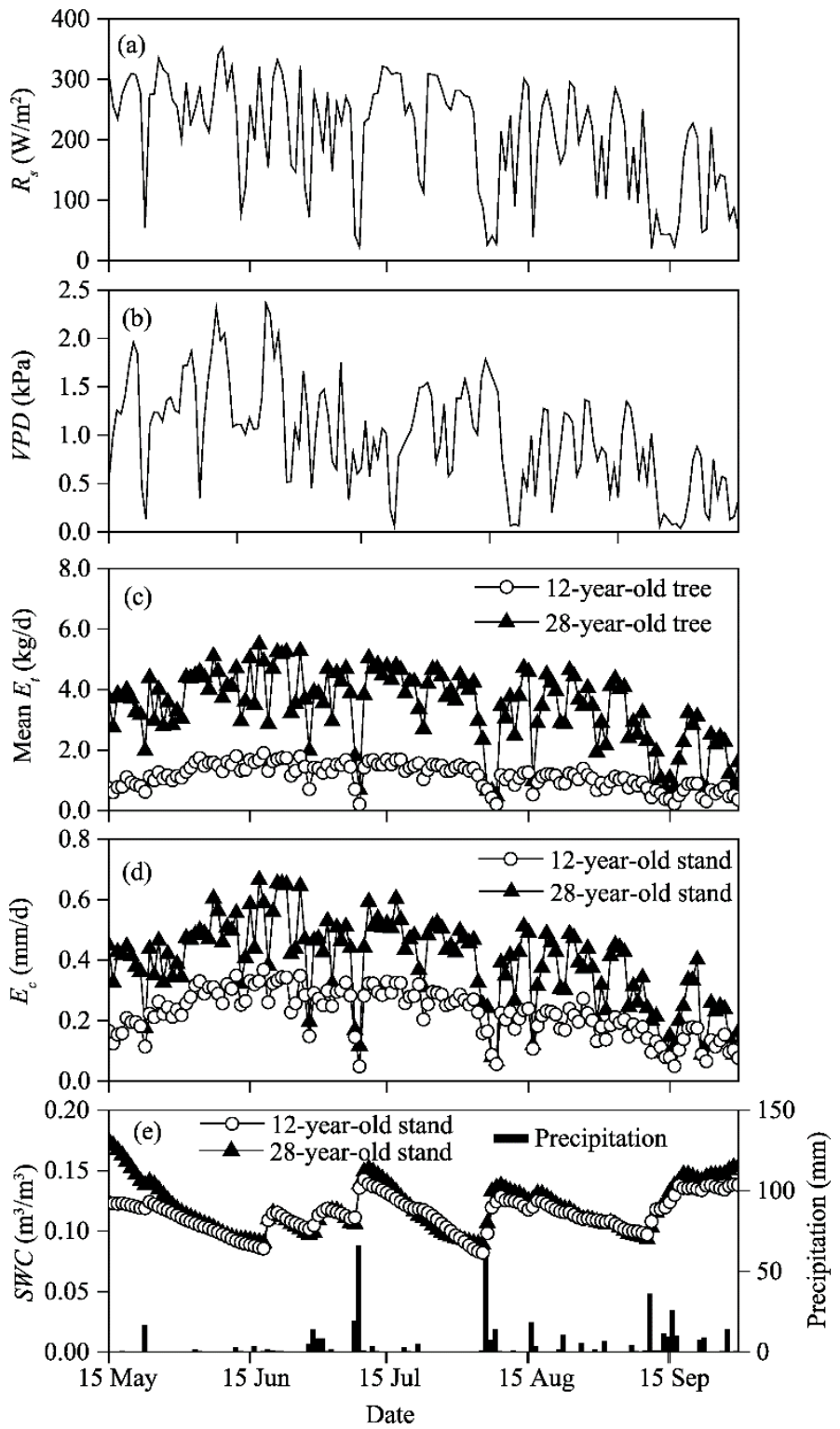

Fig. 2 Climate conditions in the Yangjuangou catchment, transpiration of trees and stands, and soil water content (SWC) in each stand from 15 May to 30 September, 2014. (a) Daily solar radiation $\left(R_{S}\right)$; (b) daily vapor pressure deficit $(V P D)$; (c) daily mean tree transpiration $\left(E_{t}\right)$; (d) daily stand transpiration $\left(E_{c}\right)$; (e) daily precipitation $(\mathrm{P})$ as well as mean volumetric soil water content in the soil depth of $0-180 \mathrm{~cm}$ within each stand.

28 -year-old trees was $0.8 \mathrm{~cm}$, which was lower than that of 12-year-old trees $(0.9 \mathrm{~cm})$. The $A_{S T}$ was $314.8 \mathrm{~cm}^{2}$ in the 28 -year-old stand while it was $394.4 \mathrm{~cm}^{2}$ in the 12 -year-old stand. The average LAI (leaf area index) was 2.77 for the 12-year-old stand and 2.38 for the 28-year-old stand.

\section{$2.3 \quad F_{d}$ and $E_{t}$}

On sunny days (i.e. 20 May and 26 July), the average $F_{d}$ of sample trees in the two stands showed a similar pattern. For the two stands, $F_{d}$ was approximately zero from 00:00 to 06:00, reached the peaks approximately at 11:00-12:00, and then decreased in the afternoon (Fig. 3). The diurnal courses of $R_{s}$ and VPD lagged behind $F_{d}$. The daytime mean $F_{d}$ of sample trees was higher in the older stand than in the younger stand. The maximum diurnal $F_{d}$ in the older stand was generally double the younger stand. The mean monthly $F_{d}$ of sample trees was significantly higher in the 
28 -year-old stand than in the 12 -year-old stand (paired $t$-test, $P<0.01$ ) (Table 2). Moreover, $E_{t}$ in the 28-year-old stand was also higher than that in the 12-year-old stand (Fig. 2c).
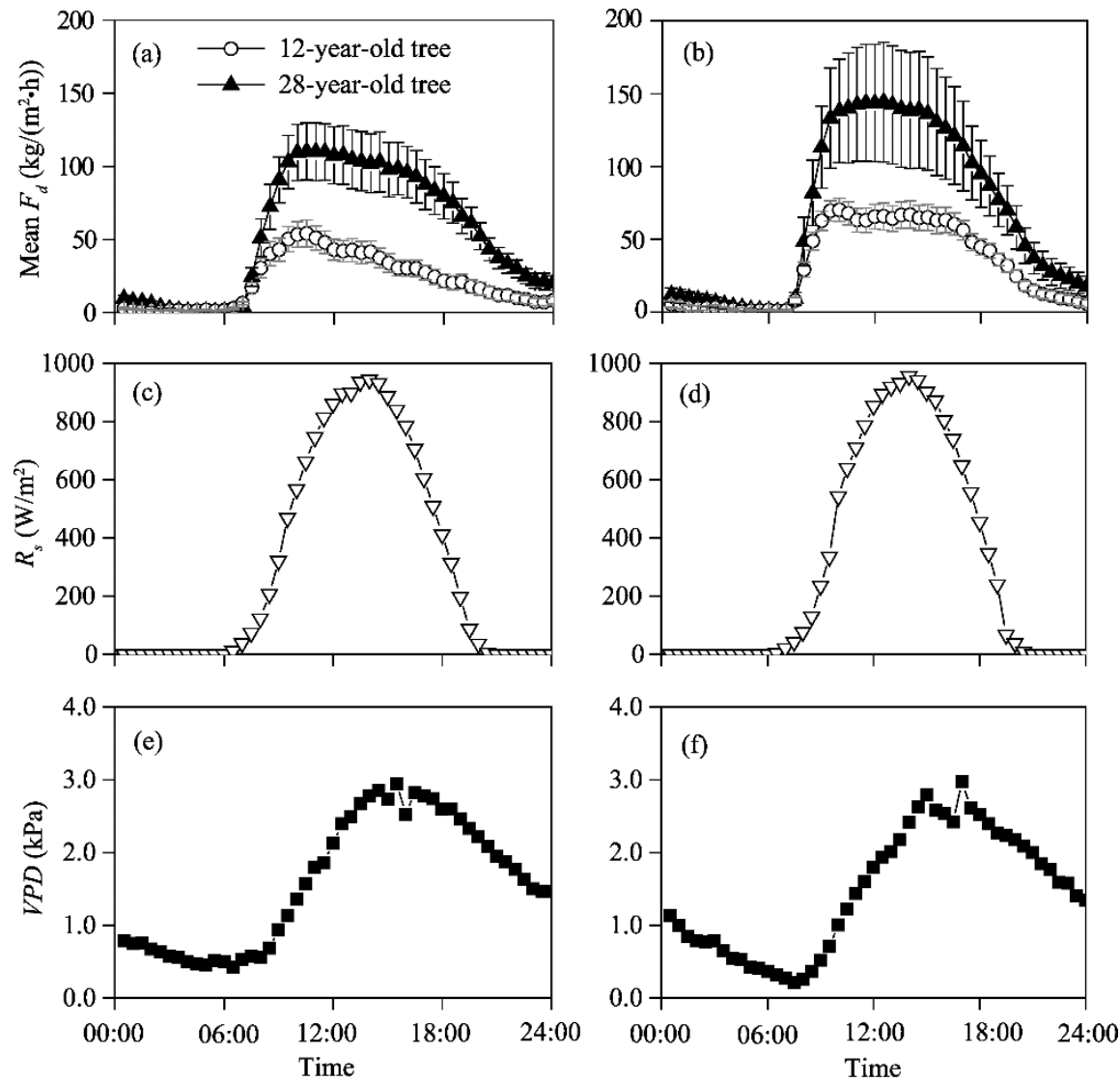

20 May 2014

26 July 2014

Fig. 3 Diurnal courses of mean sap flux density $\left(F_{d}\right)$ of 12-year-old and 28-year-old sample trees $(\mathrm{a}, \mathrm{b})$, solar radiation $\left(R_{s} ; \mathrm{c}, \mathrm{d}\right)$ and vapor pressure deficit $(V P D ; \mathrm{e}, \mathrm{f})$ on 20 May 2014 (a, c, e) and 26 July 2014 (b, d, f). Bars represent standard errors.

Table 2 Mean monthly tree sap flow density $\left(F_{d}\right)$ and stand sap flow density $\left(J_{s}\right)$ in the 12-year-old and 28-year-old stands during the growing season of 2014

\begin{tabular}{|c|c|c|c|c|}
\hline \multirow{2}{*}{ Month } & \multicolumn{2}{|c|}{ Mean $F_{d}\left(\mathrm{~kg} /\left(\mathrm{m}^{2} \cdot \mathrm{d}\right)\right)$} & \multicolumn{2}{|c|}{$J_{s}\left(\mathrm{~kg} /\left(\mathrm{m}^{2} \cdot \mathrm{d}\right)\right)$} \\
\hline & 12-year-old stand & 28-year-old stand & 12-year-old stand & 28-year-old stand \\
\hline May & 507.5 & 949.3 & 495.3 & $1,207.0$ \\
\hline June & 781.4 & $1,204.8$ & 752.3 & $1,595.2$ \\
\hline July & 725.4 & $1,123.2$ & 694.5 & $1,446.9$ \\
\hline August & 527.7 & 905.9 & 505.4 & $1,132.6$ \\
\hline September & 354.8 & 637.8 & 340.0 & 767.3 \\
\hline
\end{tabular}

\section{$2.4 J_{s}$ and $E_{c}$}

$J_{s}$ was higher in the 28-year-old stand than in the 12-year-old stand (Table 2). $E_{c}$ was also significantly higher in the 28-year-old stand than in the 12-year-old stand (paired $t$-test, $P<0.001$ ) with the values of 0.39 and $0.22 \mathrm{~mm} / \mathrm{d}$, respectively (Fig. 2d). The dynamic patterns of $E_{c}$ in both stands were similar, with daily $E_{c}$ increased at the beginning of the study period. The maximum daily $E_{c}$ occurred on 17 June for the 28-year-old stand and 18 June for the 12-year-old stand. From then on, daily $E_{c}$ showed a decreasing trend in the two stands. Cumulative $E_{c}$ was $54 \mathrm{~mm}$ in the 28-year-old stand and $31 \mathrm{~mm}$ in the 12-year-old stand during the whole study period. 


\subsection{Stomatal conductance $\left(g_{s}\right)$}

Under similar light conditions, the $g_{s}$ value of all sample trees in the different $D B H$ classes was higher in the 28-year-old stand than in the 12-year-old stand (Fig. 4). The mean $g_{s}$ for sample trees were 0.15 and $0.28 \mathrm{~mol} /\left(\mathrm{m}^{2} \cdot \mathrm{s}\right)$ in the 12-year-old and 28 -year-old stands, respectively.
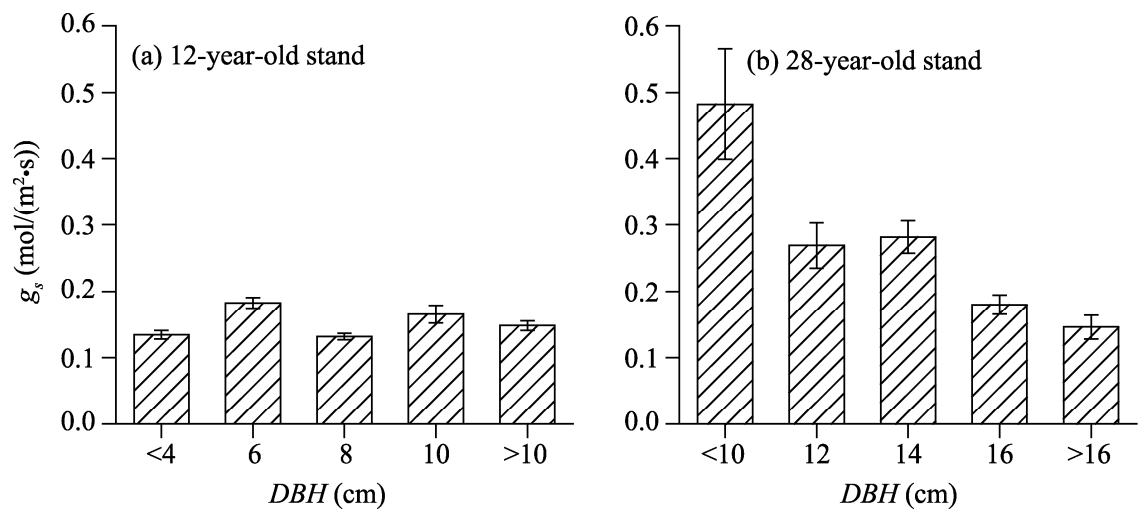

Fig. 4 Leaf stomatal conductance $\left(g_{s}\right)$ of sample trees in the (a) 12-year-old stand and (b) 28-year-old stand under different $D B H$ (diameter at breast height) classes. Bars mean standard errors.

\subsection{Relationship between $F_{d}$ and VPD}

Daily mean $F_{d}$ in both stands showed similar responses to $V P D$, wherein an exponential saturation model explained the relationships between $F_{d}$ and VPD for the 12-year-old and 28-year-old stands (Eqs. 13 and 14, respectively). The slope of the $F_{d^{-}} V P D$ relationship in the 28-year-old stand was higher than that in the 12-year-old stand (Fig. 5).

$$
\begin{aligned}
& F_{d}=1231.93 \times\left(1-\mathrm{e}^{-2.22 \times V P D}\right)\left(R^{2}=0.54, n=139\right), \\
& F_{d}=714.92 \times\left(1-\mathrm{e}^{-2.60 \times V P D}\right)\left(R^{2}=0.74, n=139\right) .
\end{aligned}
$$

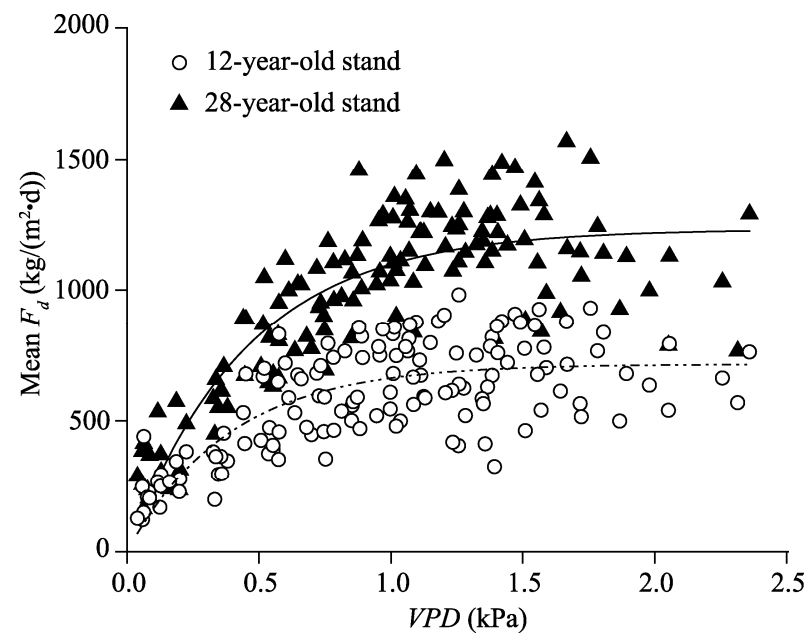

Fig. 5 Relationship of mean $F_{d}$ and $V P D$ in the 12-year-old and 28-year-old stands

\subsection{Increase in $\boldsymbol{F}_{d}$ after rainfall}

The relationship between mean $F_{d}$ and $V P D$ after rainfall differed from that before rainfall in the 12-year-old stand (Fig. 6a). When VPD remained stable, mean $F_{d}$ was higher after rainfall compared to before rainfall. Moreover, the same pattern was also found in the 28 -year-old stand (Fig. 6b). Compared to before rainfall, the degree of increase in mean $F_{d}$ for sample trees after rainfall was higher in the 28 -year-old (increase by $9 \%$ ) than in the 12-year-old stand (increase by $5 \%$ ), where $V P D$ ranged from 0.5 to $2.5 \mathrm{kPa}$. 

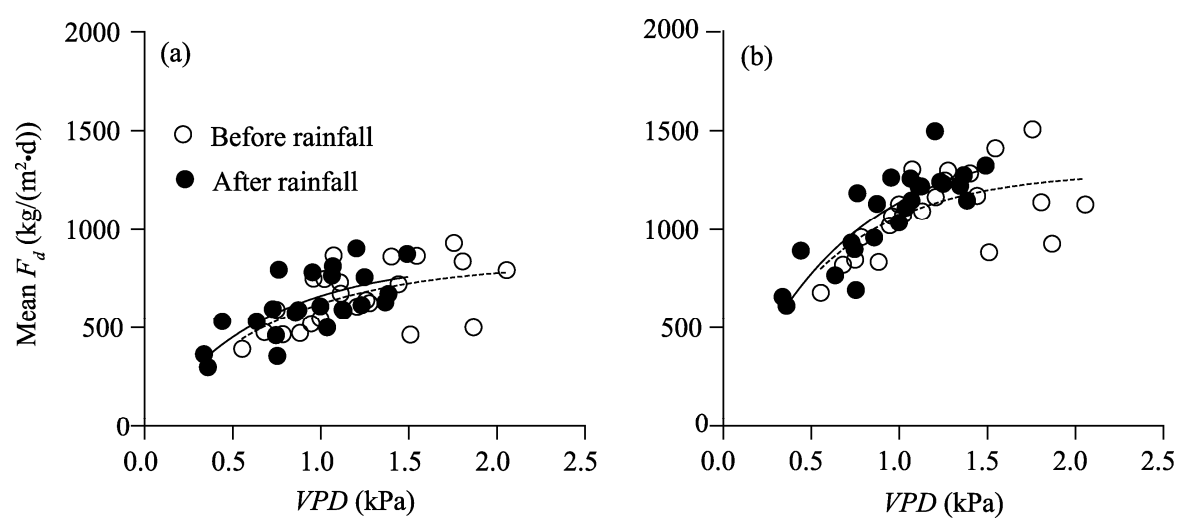

Fig. 6 Daily mean sap flux density $\left(F_{d}\right)$ of sample trees in relation to daily vapor pressure deficit $(V P D)$ before and after rainfall in the (a) 12-year-old stand and (b) 28-year-old stand

\section{Discussion}

\subsection{Transpiration at the tree and stand scales}

$F_{d}$ and $A_{s}$ are the two main factors for estimating transpiration at the tree and stand scales using thermal dissipation probes (TDPs) (Granier, 1987; Kumagai et al., 2008; Sun et al., 2014). Our results showed that the mean $E_{t}, F_{d}$ and $A_{s}$ in the 28-year-old stand was higher than those in the 12 -year-old stand. At the stand scale, $E_{c}$ in the 12-year-old stand was approximately $40 \%$ less than that in the 28-year-old stand, while $A_{S T}$ in the 28-year-old stand was lower than that in the 12 -year-old stand. For the 28-year-old stand with a lower $A_{s}, E_{c}$ was higher because $J_{s}$ in this stand was significantly higher than that in the 12-year-old stand. These results suggested that $J_{s}$ has a major effect on $E_{c}$ in black locust trees with different ages.

In contrast to some studies on variation in transpiration of tree stands at different ages, other researchers have come to similar conclusion that $J_{s}$ has a major effect on $E_{c}$ in different aged forests. For example, Zimmermann et al. (2000) reported that changes in $F_{d}$ among different aged Siberian pines caused a variation in $E_{c}$ along a chronosequence. Forrester et al. (2010) indicated that $E_{c}$ for 2- to 8-year-old Eucalyptus globules trees declined due to reductions in $J_{s}$ in southeastern Australia. However, other studies have suggested that variation in $A_{S T}$ causes the differences in $E_{c}$ among different ages of trees (Dunn and Connor, 1993; Alsheimer et al., 1998). With increasing age, $E_{c}$ of Norway spruce stands decreased because $A_{S T}$ decreased (Alsheimer et al., 1998). For the Eucalyptus regnans forests in Southeast Australia, mean daily $J_{s}$ was similar among different ages of forests and $A_{S T}$ decreased with age, resulting in $E_{c}$ decreasing with stand age (Dunn and Connor, 1993).

\subsection{Causes of variation in $\boldsymbol{F}_{\boldsymbol{d}}$ among different aged trees}

The coordination of plant hydraulic conductance and $g_{s}$ controls transpiration (Yoder et al., 1994; Ryan and Yoder, 1997). The $g_{s}$ regulates transpiration by decreasing hydraulic conductance to maintain the water potential gradient from soil to leaf above threshold and to avoid hydraulic failure (Zhao, 2011). However, $g_{s}$ would increase as a result of increasing hydraulic limitation, which boosts the transpiration rate of trees (Ryan et al., 2000). Previous studies have indicated that in older trees, a decrease in $g_{s}$ consequently results in a decrease in transpiration due to lower hydraulic conductance (Delzon et al., 2004; Delzon and Loustau, 2005).

Oren et al. (1996) suggested that the slope of relationship between $F_{d}$ and VPD can indicate plant hydraulic conductance from soil to leaf. A steep slope indicates larger hydraulic conductance. By comparing the slopes of relationship between $F_{d}$ and an integrated index with $V P D$ for different tree species on the Loess Plateau, Du et al. (2011) implied that the changes in hydraulic conductance among black locust trees between pre- and post-rainfall is larger than that among other tree species. In this study, although we did not calculate plant hydraulic conductance 
from sap flow and leaf-soil water potential gradient, the relationships between $F_{d}$ and $V P D$ for trees at different age classes suggested that the 28-year-old trees have greater hydraulic conductance than the 12-year-old trees. Furthermore, the results was also found for $g_{s}$ in 28-year-old and 12-year-old trees. Therefore, higher hydraulic conductance and $g_{s}$ resulted in higher $F_{d}$ for 28-year-old trees than for 12-year-old trees. Meanwhile, stand density is a key factor that impacts sapflow density at the tree and stand scales (Sun et al., 2014). In this study, lower $F_{d}$ of 12-year-old trees was probable related to higher effect of water stress on $F_{d}$ due to higher stand density (Bréda et al., 1995).

Rainfall is a key environmental factor determining water availability in arid and semi-arid regions. Rainfall fundamentally influences plant physiological processes, especially transpiration (Oren et al., 1996; Xu and Li, 2006; MacKay et al., 2012). Previous studies have shown that rainfall pulses significantly increase transpiration rate of plants (Zeppel et al., 2007; Zhao and Liu, 2010). In this study, $F_{d}$ for black locust trees increased in response to water recharge from rainfall. The degree of increase in mean $F_{d}$ after rainfall, however, was higher for 28-year-old trees than for 12-year-old trees. A possible reason for this is the difference in root systems between different aged trees. Previous studies have indicated that larger trees with higher root biomass and extensive root system can tap more water than smaller trees, thus decreasing the impact of soil water changes on transpiration (Delzon and Loustau, 2005; Kume et al., 2007). A survey of the vertical root distribution showed that the fine roots of black locust trees are concentrated in the 0-100 $\mathrm{cm}$ soil profile ( $\mathrm{Li}$ et al., 2005). As such, root density increases with age along a chronosequence for black locust trees on the Loess Plateau of China (Zhao et al., 2000; Chang et al., 2012). Our study thus suggested that the increase of $F_{d}$ after rainfall in 28 -year-old trees is higher than that in 12-year-old trees due to higher fine root biomass of 28-year-old trees.

Based on field surveys, soil moisture observation and inference, researchers pointed out that the physiological condition and growth rate of approximately 30-year-old black locust trees decreased due to soil water stress on the Loess Plateau, resulting in lower stem growth rate and ratio of $E_{c}$ to potential evapotranspiration $\left(\mathrm{ET}_{0}\right)$ compared to other forests in varied climatic regions (Wang et al., 2004; Wang et al., 2010). However, the present study showed that both transpiration at the tree and stand scales and ecophysiological characteristics related to water movement (i.e. $g_{s}$, hydraulic conductance, root system, and response of $F_{d}$ to rainfall) were higher for the 28-year-old stand than for the 12-year-old stand. These results implied that the 28-year-old trees are physiologically more active than the 12-year-old trees. This might be caused by the more conservative water strategy in the younger trees under water stress in semi-arid area (Delzon and Loustau, 2005; Kume et al., 2007).

\subsection{Implications for water resource and forest management}

The semi-arid Loess Plateau is a typically loess hilly and gully region characterized by highly spatial heterogeneity of topography. Vegetation (i.e. forest, orchard, shrub, grass and crop) cover differs significantly in this region due to human activity (Liu et al., 2012; Wang et al., 2012). Some studies have focused on transpiration variation in different vegetation and topographical positions, as well as its potential effect on the hydrological cycle in small catchments (Wang et al., 2011; Jian et al., 2015). Due to restoration practices, spatial distribution of forests with different age classes showed heterogeneity at the catchment and regional scales, yet water resource and forest management was neglected in this region (Jin et al., 2011). Our study showed that $E_{c}$ for black locust trees was significantly different between the two representative ages. Therefore, for accurately estimating vegetation transpiration and evaluating its effect on water yield at the catchment and regional scales, stand age is an essential factor to be consideration.

Forest transpiration initially increases until reaching peaks, and then decreases with age along a chronosequence (Forrester et al., 2010; Angstmann et al., 2012). According to this pattern, the forest development process along an age series can be separated into two stages (by the age of peak transpiration): increasing and decreasing stages. Such categorization is useful for predicting transpiration and water requirements of forests with different ages (Dunn and Connor, 1993; Alsheimer et al., 1998). The present study inferred that the 12-year-old trees during the study 
period are at the increasing stage. Thus, their water consumption capacity will increase in the coming years. In contrast, it is difficult to determine the development stage of the 28 -year-old trees due to the lack of relevant observations along the age series of black locust stand. Therefore, future researches need to establish a relationship between $E_{c}$ and age for black locust stands on a multi-year scale in this region.

Camarero et al. (2015) predicted that climate becomes warmer and drier. Drought has a negative effect on plants by decreasing both transpiration and productivity (MacKay et al., 2012). The experiment of the present study was conducted during only one growing season, without soil water stressing. Thus, variations in the effects of soil drought on physiological responses, transpiration and growth among different aged trees are needed to be studied in the future.

\section{Conclusions}

This study investigated the variation in transpiration for black locust stands at two representative age classes on the Loess Plateau of China. Transpiration for black locust at the tree and stand scales was higher for the 28-year-old trees than for the 12-year-old trees. Besides spatial heterogeneities in topographical position and vegetation cover, forest age should be considered to estimate and model the vegetation transpiration accurately at the catchment and regional scales. The 28-year-old trees were more physiologically active than the 12-year-old trees, which contributed to a higher $E_{c}$ in the 28-year-old stands. Despite having observed only two planting years, these findings provide basic information for water resources and forest management in this semi-arid area. Further researches should thus be conducted to observe the multi-year transpiration and examine the relationship between $E_{c}$ and age along an age series for black locust stands on the Loess Plateau.

\section{Acknowledgements}

This study was supported by the National Natural Science Foundation of China (41390462, 41201182, 31300402) and the Scientific Research Foundation for the Returned Overseas Chinese Scholars, State Education Ministry. We sincerely thank Dr. LI Zongshan for age determination of the studied stands and Dr. TANG Qiang for providing valuable comments on the manuscript. We also thank DONG Chen, FANG Weiwei, WANG Cong and YUAN Chuan for their considerable assistance in our field work. Finally, we thank the reviewers and editors for their constructive comments on the manuscript.

\section{References}

Alsheimer M, Köstner B, Falge E, et al. 1998. Temporal and spatial variation in transpiration of Norway spruce stands within a forested catchment of the Fichtelgebirge, Germany. Annales Des Sciences Forestières, 55(1-2): 103-123.

Angstmann J L, Ewers B E, Kwon H. 2012. Size-mediated tree transpiration along soil drainage gradients in a boreal black spruce forest wildfire chronosequence. Tree Physiology, 32(5): 599-611.

Bréda N, Granier A, Aussenac G. 1995. Effects of thinning on soil and tree water relations, transpiration and growth in an oak forest (Quercus petraea (Matt.) Liebl.). Tree Physiology, 15(5): 295-306.

Camarero J J, Franquesa M, Sangüesa-Barreda G. 2015. Timing of drought triggers distinct growth responses in holm oak: implications to predict warming-induced forest defoliation and growth decline. Forests, 6(5): 1576-1597.

Campbell G S, Norman J M. 1998. An Introduction to Environmental Biophysics (2 ${ }^{\text {nd }}$ ed.). New York: Springer-Verlag, 40-50.

Chang R Y, Fu B J, Liu G H, et al. 2012. Effects of soil physicochemical properties and stand age on fine root biomass and vertical distribution of plantation forests in the Loess Plateau of China. Ecological Research, 27(4): 827-836.

Chen J, Tang H P. 2016. Effect of grazing exclusion on vegetation characteristics and soil organic carbon of Leymus chinensis grassland in northern China. Sustainability, 8(1): 56.

Chen L X, Zhang Z Q, Zeppel M, et al. 2014. Response of transpiration to rain pulses for two tree species in a semiarid plantation. International Journal of Biometeorology, 58(7): 1569-1581.

Clearwater M J, Meinzer F C, Andrade J L, et al. 1999. Potential errors in measurement of nonuniform sap flow using heat dissipation probes. Tree Physiology, 19(10): 681-687.

Cornish P M, Vertessy R A. 2001. Forest age-induced changes in evapotranspiration and water yield in a eucalypt forest. Journal of Hydrology, 242(1-2): 43-63. 
David T S, Henriques M O, Kurz-Besson C, et al. 2007. Water-use strategies in two co-occurring Mediterranean evergreen oaks: surviving the summer drought. Tree Physiology, 27(6): 793-803.

David T S, Pinto C A, Nadezhdina N, et al. 2013. Root functioning, tree water use and hydraulic redistribution in Quercus suber trees: A modeling approach based on root sap flow. Forest Ecology and Management, 307: 136-146.

Delzon S, Sartore M, Burlett R, et al. 2004. Hydraulic responses to height growth in maritime pine trees. Plant, Cell and Environment, 27(9): 1077-1087.

Delzon S, Loustau D. 2005. Age-related decline in stand water use: sap flow and transpiration in a pine forest chronosequence. Agricultural and Forest Meteorology, 129(3-4): 105-119.

Du S, Wang Y L, Kume T, et al. 2011. Sapflow characteristics and climatic responses in three forest species in the semiarid Loess Plateau region of China. Agricultural and Forest Meteorology, 151(1): 1-10.

Dunn G M, Connor D J. 1993. An analysis of sap flow in mountain ash (Eucalyptus regnans) forests of different age. Tree Physiology, 13(4): 321-336.

Ewers B E, Mackay D S, Gower S T, et al. 2002. Tree species effects on stand transpiration in northern Wisconsin. Water Resources Research, 38(7): 8-1-8-11.

Ewers B E, Gower S T, Bond-Lamberty B, et al. 2005. Effects of stand age and tree species on canopy transpiration and average stomatal conductance of boreal forests. Plant, Cell and Environment, 28(5): 660-678.

Ewers B E, Mackay D S, Samanta S. 2007. Interannual consistency in canopy stomatal conductance control of leaf water potential across seven tree species. Tree Physiology, 27(1): 11-24.

Feng X M, Sun G, Fu B J, et al. 2012. Regional effects of vegetation restoration on water yield across the Loess Plateau, China. Hydrology and Earth System Sciences, 16(8): 2617-2628.

Forrester D I, Collopy J J, Morris J D. 2010. Transpiration along an age series of Eucalyptus globulus plantations in southeastern Australia. Forest Ecology and Management, 259(9): 1754-1760.

Fu B J, Chen L D, Ma K M, et al. 2000. The relationships between land use and soil conditions in the hilly area of the loess plateau in northern Shaanxi, China. Catena, 39(1): 69-78.

Granier A. 1987. Evaluation of transpiration in a Douglas-fir stand by means of sap flow measurements. Tree Physiology, 3(4): 309-320.

Irvine J, Law B E, Kurpius M R, et al. 2004. Age-related changes in ecosystem structure and function and effects on water and carbon exchange in ponderosa pine. Tree Physiology, 24(7): 753-763.

Jian S Q, Zhao C y, Fang S M, et al. 2015. Effects of different vegetation restoration on soil water storage and water balance in the Chinese Loess Plateau. Agricultural and Forest Meteorology, 206: 85-96.

Jiao L, Lu N, Sun G, et al. 2015. Biophysical controls on canopy transpiration in a black locust (Robinia pseudoacacia) plantation on the semi-arid loess plateau, China. Ecohydrology, doi: 10.1002/eco.1711.

Jin T T, Fu B J, Liu G H, et al. 2011. Hydrologic feasibility of artificial forestation in the semi-arid Loess Plateau of China. Hydrology and Earth System Sciences, 15(8): 2519-2530.

Köstner B, Falge E, Tenhunen J D. 2002. Age-related effects on leaf area/sapwood area relationships, canopy transpiration and carbon gain of Norway spruce stands (Picea abies) in the Fichtelgebirge, Germany. Tree Physiology, 22(8): 567-574.

Kumagai T, Tateishi M, Shimizu T, et al. 2008. Transpiration and canopy conductance at two slope positions in a Japanese cedar forest watershed. Agricultural and Forest Meteorology, 148(10): 1444-1455.

Kume T, Takizawa H, Yoshifuji N, et al. 2007. Impact of soil drought on sap flow and water status of evergreen trees in a tropical monsoon forest in northern Thailand. Forest Ecology and Management, 238(1-3): 220-230.

Kupper P, Sellin A, Tenhunen J, et al. 2006. Effects of branch position on water relations and gas exchange of European larch trees in an alpine community. Trees, 20(3): 265-272.

Li G Q, Xu G H, Guo K, et al. 2014. Mapping the global potential geographical distribution of black locust (Robinia pseudoacacia L.) using herbarium data and a maximum entropy model. Forests, 5(11): 2773-2792.

Li P, Zhao Z, Li Z B, et al. 2005. Characters of root biomass spatial distribution of Robinia pseudoacacia in Weibei loess areas. Ecology and Environment, 14(3): 405-409. (in Chinese)

Liu B X, Shao M A. 2016. Response of soil water dynamics to precipitation years under different vegetation types on the northern Loess Plateau, China. Journal of Arid Land, 8(1): 47-59.

Liu Y, Fu B J, Lü Y H, et al. 2012. Hydrological responses and soil erosion potential of abandoned cropland in the Loess Plateau, China. Geomorphology, 138(1): 404-414.

MacKay S L, Arain M A, Khomik M, et al. 2012. The impact of induced drought on transpiration and growth in a temperate pine plantation forest. Hydrological Processes, 26(12): 1779-1791.

Magnani F, Bensada A, Cinnirella S, et al. 2008. Hydraulic limitations and water-use efficiency in Pinus pinaster along a chronosequence. Canadian Journal of Forest Research, 38(1): 73-81.

McDowell N G, Phillips N, Lunch C, et al. 2002. An investigation of hydraulic limitation and compensation in large, old 
Douglas-fir trees. Tree Physiology, 22(11): 763-774.

Oren R, Zimmermann R, Terbough J. 1996. Transpiration in upper Amazonia floodplain and upland forests in response to drought-breaking rains. Ecology, 77(3): 968-973.

Roberts S, Vertessy R, Grayson R. 2001. Transpiration from Eucalyptus sieberi (L. Johnson) forests of different age. Forest Ecology and Management, 143(1-3): 153-161.

Röll A, Niu F, Meijide A, et al. 2015. Transpiration in an oil palm landscape: effects of palm age. Biogeosciences, 12(19): 5619-5633.

Ryan M G, Yoder B J. 1997. Hydraulic limits to tree height and tree growth. BioScience, 47(4): 235-242.

Ryan M G, Bond B J, Law B E, et al. 2000. Transpiration and whole-tree conductance in ponderosa pine trees of different heights. Oecologia, 124(4): 553-560.

Santiago L S, Goldstein G, Meinzer F C, et al. 2000. Transpiration and forest structure in relation to soil waterlogging in a Hawaiian montane cloud forest. Tree Physiology, 20(10): 673-681.

Schulze E, Kelliher F M, Korner C, et al. 1994. Relationships among maximum stomatal conductance, ecosystem surface conductance, carbon assimilation rate, and plant nitrogen nutrition: a global ecology scaling exercise. Annual Review of Ecology and Systematics, 25(1): 629-662.

Scott D F, Prinsloo F W. 2008. Longer-term effects of pine and eucalypt plantations on streamflow. Water Resources Research, 44(7), doi: 10.1029/2007WR006781.

Sun G, Zhou G Y, Zhang Z Q, et al. 2006. Potential water yield reduction due to forestation across China. Journal of Hydrology, 328(3-4): 548-558.

Sun X C, Onda Y, Otsuki K, et al. 2014. The effect of strip thinning on tree transpiration in a Japanese cypress (Chamaecyparis obtusa Endl.) plantation. Agricultural and Forest Meteorology, 197: 123-135.

Teklehaimanot Z, Jarvis P G, Ledger D C. 1991. Rainfall interception and boundary layer conductance in relation to tree spacing. Journal of Hydrology, 123(3-4): 261-278.

Thomsen J E, Bohrer G, Matheny A M, et al. 2013. Contrasting hydraulic strategies during dry soil conditions in Quercus rubra and Acer rubrum in a sandy site in Michigan. Forests, 4(4): 1106-1120.

Vertessy R A, Benyon R G, O’Sullivan S K, et al. 1995. Relationships between stem diameter, sapwood area, leaf area and transpiration in a young mountain ash forest. Tree Physiology, 15(9): 559-567.

Vertessy R A, Watson F G R, O’Sullivan S K. 2001. Factors determining relations between stand age and catchment water balance in mountain ash forests. Forest Ecology and Management, 143(1-3): 13-26.

Wang L, Shao M A, Hou Q C, et al. 2001. The analysis to dried soil layer of artificial Robinnia pseudoscacia forestry land in the Yan'an experimental area. Acta Botanica Boreali-occidentalia Sinica, 21(1): 101-106. (in Chinese)

Wang L, Shao M A, Li Y Y. 2004. Study on relationship between growth of artificial Robinia pseudoacacia plantation and soil desiccation in the Loess Plateau of northern Shannxi Province. Scientia Silvae Sinicae, 40(1): 84-91. (in Chinese)

Wang L, Wei S P, Horton R, et al. 2011. Effects of vegetation and slope aspect on water budget in the hill and gully region of the Loess Plateau of China. Catena, 87(1): 90-100.

Wang S, Fu B J, Gao G Y, et al. 2012. Soil moisture and evapotranspiration of different land cover types in the Loess Plateau, China. Hydrology and Earth System Sciences, 16(8): 2883-2892.

Wang Y L, Liu G B, Kume T, et al. 2010. Estimating water use of a black locust plantation by the thermal dissipation probe method in the semiarid region of Loess Plateau, China. Journal of Forest Research, 15(4): 241-251.

Xu H, Li Y. 2006. Water-use strategy of three central Asian desert shrubs and their responses to rain pulse events. Plant and Soil, 285(1-2): 5-17.

Yoder B J, Ryan M G, Waring R H, et al. 1994. Evidence of reduced photosynthetic rates in old trees. Forest Science, 40(3): $513-527$.

Zeppel M, Macinnis-Ng C M O, Ford C R, et al. 2007. The response of sap flow to pulses of rain in a temperate Australian woodland. Plant and Soil, 305(1-2): 121-130.

Zhang J G, Guan J H, Shi W Y, et al. 2015. Interannual variation in stand transpiration estimated by sap flow measurement in a semi-arid black locust plantation, Loess Plateau, China. Ecohydrology, 8(1): 137-147.

Zhao P. 2011. On the coordinated regulation of forest transpiration by hydraulic conductance and canopy stomatal conductance. Acta Ecologica Sinica, 31(4): 1164-1173. (in Chinese)

Zhao W Z, Liu B. 2010. The response of sap flow in shrubs to rainfall pulses in the desert region of China. Agricultural and Forest Meteorology, 150(9): 1297-1306.

Zhao Z, Li P, Wang N J. 2000. Distribution patterns of root systems of main planting tree species in Weibei Loess Plateau. Chinese Journal of Applied Ecology, 11(1): 37-39. (in Chinese)

Zimmermann R, Schulze E D, Wirth C, et al. 2000. Canopy transpiration in a chronosequence of Central Siberian pine forests. Global Change Biology, 6(1): 25-37. 